\title{
Impact of ozonation process on the microbiological and antioxidant status of raspberries (Rubus ideaeus L.) during storage at room temperature
}

\author{
Tomasz Piechowiak, Piotr Antos, Patryk Kosowski, Karol Skrobacz, Radosław Józefczyk and Maciej Balawejder \\ Department of Chemistry and Food Toxicology, Faculty of Biology and Agriculture, University of Rzeszów, \\ St. Ćwiklińskiej 1a, 35-601 Rzeszów \\ e-mail: maciejb@ur.edu.pl
}

\begin{abstract}
In this study the effect of the ozone exposure on the microbiological and antioxidant status of raspberries stored at room temperature was investigated. The study revealed that ozonation with a dose of 8-10 ppm for $30 \mathrm{~min}$, once every 12 hours, for 3 days effectively reduced the growth of aerobic mesophilic bacteria and fungi. On the last day of storage, the level of infestation of control fruit with Botrytis cinerea reached $100 \%$, while for the ozonated fruit it was only $12 \%$. Fruits exposed to ozone exhibited higher antioxidant content due to lower loss of polyphenols compared to their untreated counterparts. The procedure applied was proven to be effective and indicated the potential of ozone to extend shelf-life of raspberries kept at room temperature.
\end{abstract}

Key words: raspberry, antioxidant capacity, ozone, gray mold

\section{Introduction}

A balanced diet contains adequate portions of fruit and vegetables supplying nutrients to ensure proper functioning of the human organism and reducing the risk of degenerative diseases. Raspberries (Rubus ideaus L.) are characterized by a wide range of compounds with documented antioxidant properties, i.e. vitamin C, phenolic acids, polyphenols, including ellagitannins, tannins and flavonoids. It is proven that these compounds help to protect the human body from oxidative stress which may result in cancers, cardiovascular and neurodegenerative diseases (Norberto et al. 2015).

Raspberries are very fragile and must be transported as quickly as possible for further processing or storage. Unfavorable quality changes due to respiration, transpiration and ripening are already observed in a few hours after harvest. They cause losses in individual characteristics that shape sensory and biological value, i.e. sugar content, acidity, vitamins, polyphenols, loss of weight and reduced firmness. In addition, the major problem is the growth of undesirable microflora, mainly molds of the genus Botrytis. This forces many producers of raspberries to use synthetic pesticides, already at the flowering stage. However, in harvested fruit, residues of plant protection products are detected, which can adversely affect the well-being and health of humans after ingestion. It is therefore important to search for technologies that can effectively reduce microbial contamination and leave no harmful residues on the product. An alternative to traditional fruit preservation techniques may be ozone technology (Carletti et al. 2013).

Ozone is a substance with a strong oxidation potential that has a strong bacteriophage and fungicidal impact. There is an evidence that ozone and its degradation products can oxidize important components of the microbial cell membrane, resulting in a damage to the membrane, leakage of the contents and finally cell lysis, and oxidation of the internal cell components (Khadre et al. 2001). Due to this valuable property, it can widely be used in preserving the quality of fruit at each stage of production, e.g. transportation, sorting, storage, packaging and also as a preprocessing element. A number of studies showed a beneficial impact of ozonation on the quality of fruit during storage (Barth et al. 2006, Botondi et al. 2015, Chwaszcz et al. 2015). It was concluded that preservation effect of ozone was dependent on the ozone doses, exposition time of fruit to this agent, the number of ozonation cycles and indirectly on the properties of particular plant raw material. Moreover, Skog and Chu (2001) have proven that gaseous ozone can oxidize ethylene which is responsible for ripening of fruit. As a result, the processes related to losses of chemical compounds and fruit softening are slowed down. An additional benefit of ozone utilization is its ability to reduce pesticide residues (Sadło et al. 2017). Balawejder et al. (2014b) indicated that ozone exposure could reduce the pesticide residue content on raspberries and blackcurrants for about $60 \%$. In the patent PL 407854, a technology and device for the storage of raspberries in the ozone enriched atmosphere were described. The procedure proposed for raspberry ozonation with an ozone dose of 8-10 ppm for $30 \mathrm{~min}$, once every $12 \mathrm{~h}$ 
allowed preservation of the fruit quality by limitation of losses caused by growth of microorganisms and physiological processes. The device for realization of this method consists of a number of chambers separated from each other and from the environment. Each of them is connected via a valve and pipeline to the ozone generator, has a sealed opening on the front, and is equipped with a diaphragm with an residual ozone destructor (Balawejder et al. 2014a).

The presented work complements the research undertaken on the effectiveness of ozone as a factor extending the storage life of stored fruit. The purpose of the study was to determine the ozone effect on the microbial state of raspberry fruit and changes in antioxidant status during storage at room temperature.

\section{Materials and methods Reagents and devices}

Reagents: bought from BTL (Łódź, Poland): Czapek solution agar, nutrient agar; Sigma Aldrich (Darmstadt, Germany): quercetin ( $\geq 95 \%)$, trolox (97\%), potassium chloride ( $\geq 99 \%)$; DPPH (2,2'-diphenyl-1-picrylhydrazyl $\geq 95 \%)$, ABTS (2,2'-azino-bis(3-ethylobenzothiazoline-6-sulphonic acid)) ( $\geq 98 \%)$, Gallic acid ( $\geq 98 \%)$, neocuproine (2,9-dimethy-1,10-phenantroline $\geq 98 \%$ ); Chempur (Piekary Śląskie, Poland): Folin-Ciocalteu reagent, sodium carbonate $(99,8 \%)$, ammonium acetate $(\geq 97 \%)$, sodium nitrate (III) $(98 \%)$, sodium hydroxide $(98,8 \%)$, sodium thiosulfate; POCH (Gliwice, Polska): methanol, copper ( II) chloride, hydrochloric acid 35-38\%, Aluminium chloride anhydrous, sodium acetate anhydrous, sodium chloride (99\%), 2,6-dichlorophenoloindophenol (99\%), oxalic acid (99,75\%).

Devices: ozone generator model A 02/10 (CSI Ekotech, Piotrków Trybunalski, Poland), ozone analyzer, model 106M (2B Technologies), UV-Vis absorption spectrophotometer, laboratory centrifuge (MPW, Warszawa-Poland), homogenizer (Bosch), laboratory incubator, pH-meter (Elmetron, Zabrze-Poland).

\section{Plant material for the research}

Fresh raspberries (Rubus idaeus L.) were purchased directly from the grower. The raspberries were fully coloured, mature and ready for consumption, without signs of mold infestation or mechanical damage.

\section{Storage procedure}

\section{Fruit ozonation in laboratory scale experiment}

Raspberries were divided into two parts, each about $1 \mathrm{~kg}$. Then, they were evenly distributed in containers with a perforated pallet and a lid. One part of the fruit was a blank test and the other part was an ozonated sample. Raspberries (both control and ozonated) were stored at room temperature $\left(20-25^{\circ} \mathrm{C}\right.$ ) for a period of 72 hours.

Raspberries were ozonated during total time of experiment, daily, at 12-hour intervals, for 30 min, keeping the ozone concentration in the container at 8-10 ppm. After the process had been finished, the container was sealed and stored. Samples for analysis were collected after 24, 48 and 72 hours of storage. The experiment was performed in triplicate.

\section{Microbiological analysis of fruit samples}

Determination of the degree of contamination with microorganisms by spread plate method

The microbiological analysis of the control and ozonated fruit was carried out prior to storage, as well as after 24 , 48,72 hours of storage, using the spread plate method for aerobic mesophilic bacteria and the total number of fungi. Agar media were prepared according to ISO / TS 11133-1: 2009 (ISO 2009). For the analysis randomly collected $(50 \mathrm{~g})$ raspberries from each batch of fruit were homogenized. Next, the resulting homogenate was diluted in the saline solution to the concentration from $10^{-1}$ to $10^{-6}$ by a series of consecutive dilutions. While maintaining the sterile culture conditions, further dilutions of the sample were plated using the spread plate method. The total number of aerobic mesophilic bacteria was determined using nutrient agar, where the cultivation conditions were $30{ }^{\circ} \mathrm{C}$ for $72 \mathrm{~h}$. The total number of fungi was determined using Czapek solution agar and cultivation conditions were $28^{\circ} \mathrm{C}$ for $168 \mathrm{~h}$. The number of colonies per plate was calculated, and then the result was shown as log $\mathrm{cfu}$ in $1 \mathrm{~g}$ of fruit sample. The analyses were performed in 3 replications. 


\section{Visual evaluation of the degree of fruit infestation by gray mold}

Assay included a direct visual control of the amount of fruit affected by gray mold after 72 hours of storage and the assessment of its percentage in comparison to the total number of fruit.

\section{Analysis of the changes in antioxidant potential}

Preparation of fruit samples to analyses

Samples of $20 \mathrm{~g}$ of the ozonated and control fruit were homogenized in a $60 \mathrm{ml}$ 1:1 methanol-water mixture, which was followed by centrifugation at $15000 \mathrm{rpm}$ for one minute. The supernatant obtained was analyzed.

\section{Determination of the vitamin C content with Tillmans method}

$5 \mathrm{~g}$ of fruit was homogenized with $50 \mathrm{ml} 2 \%$ solution of oxalic acid. Next, it was vigorously shaken and incubated in darkness for $15 \mathrm{~min}$. The resulting suspension was filtered and the filtrate was analyzed.

A $10 \mathrm{ml}$ sample of filtrate was immediately titrated with a standard solution of 2,6-dichlorophenolindophenol at the concentration $25 \mathrm{mg}$ in $100 \mathrm{ml}$. The titration was performed in triplicate for each filtrate, while the whole assay was made for 3 samples of ozonated and 3 samples of control fruit. In order to determine the vitamin C content of the fruit samples, the following formula was used:

$$
C=\frac{V \cdot M \cdot K_{m}}{V_{p} \cdot m} \cdot 100,\left[\mathrm{mg} \cdot 100 \mathrm{~g}^{-1}\right]
$$

where: $V=$ volume of DCPiP used during titration $[\mathrm{ml}], M=$ concentration of standard solution DCPiP, $V k m=$ volumetric flask volume $[\mathrm{ml}], V p=$ filtrate volume $[\mathrm{ml}], m=$ fruit mass $[\mathrm{g}]$.

\section{Determination of antioxidant activity using $\mathrm{ABTS}^{\bullet+}$ radical}

A $7 \mathrm{mM}$ solution of ABTS in water solution of $2.45 \mathrm{mM} \mathrm{K}_{2} \mathrm{~S}_{2} \mathrm{O}_{8}$ was prepared. Next, it was incubated in darkness for $24 \mathrm{~h}$. Before the actual analysis the radicals solution of ABTS $^{\circ+}$ was diluted with distilled water until the absorbance $0.7 \pm 0.02$, at $\lambda=734 \mathrm{~nm}$ was achieved.

A $1 \mathrm{ml}$ solution of $\mathrm{ABTS}^{*+}$ radicals was placed into a glass tube, and $10 \mu \mathrm{l}$ of the sample prepared for analysis was added. After six minutes of incubation in darkness, the absorbance of the solutions was measured at $\lambda=734 \mathrm{~nm}$ (using a blank sample as reference). The antioxidant activity was determined based on a calibration curve for 100 $\mu \mathrm{M}-1.5 \mathrm{mM}$ trolox solutions in methanol. For each sort of fruit 6 independent repetitions of the antioxidant activity measurements were performed. The obtained results are presented as an equivalent of $\mu$ mol of trolox in $100 \mathrm{~g}$ of fresh fruit mass.

\section{Determination of antioxidant activity using $\mathrm{DPPH}^{\bullet}$ radical}

Freshly prepared methanol solution of $\mathrm{DPPH}^{\bullet}$ radicals at a concentration of $100 \mu \mathrm{M}$ was diluted until its absorbance reached $1.00 \pm 0.02$, at $\lambda=515 \mathrm{~nm}$.

A $1 \mathrm{ml} \mathrm{DPPH}{ }^{*}$ radical solution was placed into a glass tube, and next $30 \mu \mathrm{l}$ of the fruit sample was added. After 30 min of incubation in darkness, the solutions absorbance was measured at $\lambda=515 \mathrm{~nm}$ (using a blank sample as a reference). The antioxidant activity was determined based on the calibration curve for $50 \mu \mathrm{M}-1 \mathrm{mM}$ of trolox solutions in methanol. For each sort of fruit 6 independent repetitions of the antioxidant activity measurements were performed. The obtained results are presented as an equivalent of $\mu \mathrm{mol}$ of trolox in $100 \mathrm{~g}$ of fresh fruit mass.

\section{Determination of the antioxidant activity using CUPRAC method}

$1 \mathrm{ml} 0.0075 \mathrm{M}$ neocuproine solution, $1 \mathrm{ml} 1 \mathrm{M} \mathrm{NH}_{4} \mathrm{Ac}, 1 \mathrm{ml}$ of the research sample and $0.1 \mathrm{ml}$ of distilled water were added into $1 \mathrm{ml}$ of $0.001 \mathrm{M} \mathrm{CuCl}_{2}$ solution. The reaction mixture was incubated for $30 \mathrm{~min}$ at room temperature $\left(20-25^{\circ} \mathrm{C}\right)$ in darkness. Next, the absorbance was measured at $\lambda=450 \mathrm{~nm}$ (using a blank sample as a reference). To assess the antioxidant activity of the research samples, a calibration curve for 1-500 $\mu \mathrm{M}$ of trolox solutions in methanol was utilized. For each measurement 6 independent repetitions were conducted. The obtained results are presented as an equivalent of $\mu \mathrm{mol}$ of trolox per $100 \mathrm{~g}$ of fresh fruit. 


\section{Determination of the total phenolic compounds content}

A $0.25 \mathrm{ml}$ of Folin-Ciocalteu reagent that was diluted $1: 1$ with a distilled water and $0.5 \mathrm{ml}$ of $7 \% \mathrm{Na}_{2} \mathrm{CO}_{3}$ solution were added into $5 \mathrm{ml}$ of hundredfold diluted research sample. After 30 minutes of incubation at room temperature $\left(20-25^{\circ} \mathrm{C}\right)$ in darkness, the absorbance was measured at $\lambda=750 \mathrm{~nm}$ (using a blank sample as reference). To assess the total phenolic compounds content of the research samples, a calibration curve for 0.1-1 mg $100 \mathrm{ml}^{-1}$ gallic acid in methanol solution was used. For each measurement 6 independent repetitions were conducted. The obtained results were presented as an equivalent of $\mathrm{mg}$ of gallic acid per 100g of fresh fruit (Ozyurt et al. 2011).

\section{Determination of the total anthocyanin with Francis-Fuleki method}

A $12.5 \mathrm{ml} 0.4 \mathrm{M}$ sodium acetate $/ \mathrm{HCl}$ at $\mathrm{pH} 4.5$, and $0.5 \mathrm{ml}$ of the investigated fruit samples were added into 12.5 $\mathrm{ml} 0.025 \mathrm{M} \mathrm{KCl} / \mathrm{HCl}$ at $\mathrm{pH}$ 1.0. Next, the absorbance of each solution was measured at wavelength $\lambda=510 \mathrm{~nm}$

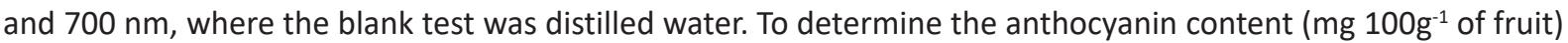
calculated as equivalent of cyanidin-3-glucoside, the following formulas were used:

$$
\begin{aligned}
& \mathrm{A}=\left[\left(\mathrm{A}_{510}-\mathrm{A}_{700}\right)_{\mathrm{pH}=1}\right]-\left[\left(\mathrm{A}_{510}-\mathrm{A}_{700}\right)_{\mathrm{pH}=4.5}\right] ; \\
& {\left[\mathrm{mg} \mathrm{l}^{-1}\right]=\frac{A \cdot M W \cdot D F \cdot 1000}{\varepsilon \cdot l}}
\end{aligned}
$$

where: $\mathrm{A}=$ the calculated absorbance of the solutions in given environment, $\mathrm{MW}=$ molecular weight of cyanidin-3-glucoside $\left(449.2 \mathrm{~g} \mathrm{~mol}^{-1}\right), \mathrm{DF}=$ the dilution factor, $\varepsilon=$ molar absorption coefficient of the dye $\left(26900 \mathrm{dm}^{3}\right.$ $\left.\mathrm{mol}^{-1} \mathrm{~cm}^{-1}\right), \mathrm{I}=$ the path length of the beam of light through the material sample $(1 \mathrm{~cm})$ (Giusti and Wrolstadt 2001).

\section{Statistical analysis}

To test the statistical significance of the effect of the ozonation process on a given qualitative parameter, the Student's t-test was used for independent samples, with significance level $p=0.05$. The significance of the differences was checked for each term of analysis. Furthermore, the effect of storage time on the specified quality parameter of the control and ozonated fruit in relation to the value of the specified quality parameter before storage was determined using a one-way ANOVA and t-Tukey test for unequal sample sizes $(p=0.05)$. These analyzes were performed in STATISTICA12.5 PL from StatSoft company.

\section{Results and discussion \\ Microbial status of fruit}

Raspberry fruit is metabolically active and undergoes an adverse quality changes in a few hour after harvest. However, it is not always possible to keep the fruit in cold conditions, e.g. during transport of fruit from the plantation to the processing plant or storage chambers, distribution in warehouses and between individual stages of technological process in fruit processing (Carletti et al. 2013). Therefore, in this study the impact of ozonation process on the microbial contamination was examined in raspberries stored at room temperature.

The procedure of daily ozonation of raspberry fruit with an ozone dosage of 8-10 ppm for 30 minutes once every 12 hours during the whole storage period had a statistically significant impact on the inhibition of the development of microorganisms responsible for deterioration of fruit quality. The results of analysis of the total number of aerobic mesophilic bacteria and the total number of fungi are presented as graphs of the number of colonies forming units versus time of storage for ozonated and control fruit (Figs. $1 \mathrm{~A}$ and B).

One-way analysis of variance (ANOVA) showed that the storage time had a statistically significant impact on the development of mesophilic aerobic bacteria for both ozonated and control fruit $(p<0.05)$. The initial microbial load was $5.24 \pm 0.46 \mathrm{log}_{\mathrm{cfu} \mathrm{g}}{ }^{-1}$. After 24 hours of storage, a statistically significant growth of bacteria on the control fruit was observed up to $6.90 \pm 0.24 \mathrm{log}_{\mathrm{cfu} \mathrm{g}}{ }^{-1}(p<0.05)$. In subsequent days of analysis, the growth of bacteria was not statistically significant based on the $t$-Tukey test $(p>0.05)$. The procedure of fruit storage in the ozone enriched atmosphere resulted in inhibition of the growth of aerobic bacteria, which is indicated by statistically 
significant lower count of colony forming units on the ozonated fruit compared to control fruit during the whole period of the storage experiment $(p<0.05)$. The most noticeable ozone effect was observed after 48 hours of storage. At that time it was observed that the count of colony forming units on the raspberry fruit was lower by 1.18 $\log \mathrm{cfu} \mathrm{g}^{-1}$ (Fig. 1A).
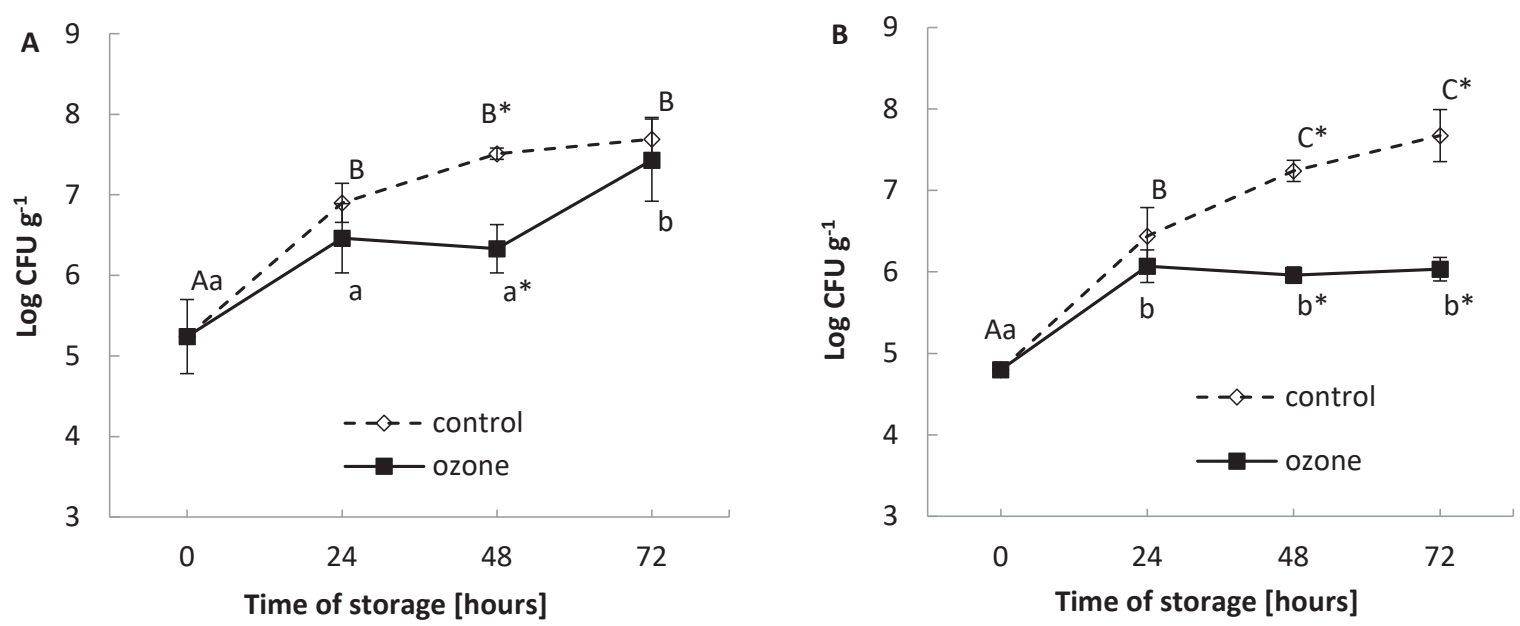

Fig. 1. Impact of ozonation on the total count of mesophilic aerobic bacteria (A) and total count of fungi (B) in the raspberry fruit stored under non cold storage ambient conditions. Mean values with the same lower (changes over time for control fruit) or upper (changes over time for ozonated fruit) case are not statistically significant according to the t-Tukey test ( $p=0.05)$. The mean values highlighted "*" in a given day of storage are mutually significantly different according to the Student's t-test $(p=0.05)$.

According to the literature, the fungal growth is correlated with the storage time and storage conditions (Zavala et al. 2004). In our research we also observed a clear correlation of fungi colony forming units count with time for both control fruit and ozonated fruit. The total count of fungi before the storage experiment was $4.8 \pm 0.09$ $\log \mathrm{cfu} \mathrm{g}^{-1}$. During the conducted tests, a statistically significant and systematic growth of the fungal colony forming units on control fruit was observed. At the end of the experiment, this value was higher by $2.87 \log ^{\mathrm{cfu}} \mathrm{g}^{-1}$ in comparison to the initial value (Fig. 1B). The analyzes indicated that the ozone dose and exposure time had effectively reduced the development of fungi that deteriorated fruit quality. Although after 24 hours of storage of the ozonated fruit, a statistically significant growth of fungal colonies was observed, no significant changes in the studied parameters were noticed. After 48 and 72 hours, the number of fungal colonies on the ozonated fruit was respectively 1.28 and $1.64 \mathrm{log} \mathrm{cfu} \mathrm{g}^{-1}$ lower than on the control fruit $(p<0.05)$. Similar correlations were observed by Aguayo et al. (2006), who examined the level of microbial contamination in tomatoes treated with ozone at a concentration of $4 \pm 0.5 \mathrm{ppm}$, every 3 hours, for the entire storage period. The authors have shown that the procedure used successfully limited the development of mesophilic aerobic bacteria as well as fungi. At the last day of experiment the authors observed lower counts of mesophilic aerobic bacteria by 1.1 log cfu g-1 and fungi by $1.75 \mathrm{log} \mathrm{cfu} \mathrm{g}^{-1}$ on the ozonated fruit in comparison to control fruit.

The efficacy of protective effect of ozone exposure depends mainly on the ozone dose, exposure time, the number of ozonation cycles and indirectly on the product properties and the resistance of microorganisms. In the research by Yeoh et al. (2014) prolonging the time of ozonation, with the ozone dose of $9.2 \pm 0.2 \mathrm{ppm}$, resulted in a greater reduction of microorganisms responsible for fruit deterioration. However, prolonging the exposure time can compromise some qualitative features of ozonated fruit. In turn, in the research of Concha-Meyer et al. (2015) it was concluded that ozonation of highbush blueberry with the ozone dose of $4 \mathrm{ppm}$ had no protective effect on the fruit quality at temperatures $4^{\circ} \mathrm{C}$ and $12{ }^{\circ} \mathrm{C}$, which had presumably been a result of an inadequate ozone dose.

The degree of fruit infestation by gray mold (Botrytis cinerea) can be assessed visually. Gray mold (Botrytis cinerea) occurs as a characteristic, gray rash on fruit (Matiacevich et al. 2013) and its development is accompanied by softening of fruit and the leakage of juice. The degree of fruit infestation by gray mold was verified at 72 hour of the experiment. It was observed that storage in ozone-enriched atmosphere protected raspberry fruit from the development of gray mold, which was evidenced by only $12 \%$ infestation on the ozonated fruit, while at the same time $100 \%$ of the control fruit were infected with this fungus. The mentioned above research clearly indicate the efficacy of ozone as a factor improving the shelf life of raspberry fruit due to its bactericidal and fungicidal action. 


\section{Antioxidant potential \\ Changes in the vitamin $\mathrm{C}$ content}

Ozone is considered as a substance that can induce the reactive oxygen species generation in plant cells (Kangasjärvi et al. 2005). Therefore, the investigation of antioxidant compounds content, such as total phenolic compounds, vitamin C, and total antioxidant activity in ozonated fruit should be also carried out. The impact of ozonation on the antioxidants level is significantly associated with process and storage conditions (Carletti et al. 2013, Botondi et al. 2015). The use of high ozone concentration results in a significant decrease of antioxidants content in berries, which is connected with occurrence of oxidative stress in plant cells (Ali et al. 2014). However, the application of "mild" process conditions reduces the antioxidant compounds losses in fruit during storage or even induces an increase of antioxidants level in comparison to the initial value (Zhang et al. 2011).

Changes in the vitamin C content during the storage are presented in Figure 2. Directly after the harvest, the content of vitamin C in the fruit was $11.98 \pm 0.5 \mathrm{mg}$ per $100 \mathrm{~g}$ of the fruit. The vitamin C content is susceptible to changes related to storage and is the most labile of all antioxidants (Zhang et al. 2011). Also in our research we observed a statistically significant and continuous loss of the vitamin $\mathrm{C}$ during the storage. The procedure of the raspberry ozonation had no impact on the vitamin C content up to 48 hours of the storage $(p>0.05)$. However, after 48 hours of experiment, it was observed that the reduction of vitamin C content in fruit was significantly lower in the ozonated fruit than in control fruit, i.e. the vitamin C concentration was $28 \%$ higher in the ozonated raspberry than in control raspberry fruit. At the end of experiment vitamin C content decreased by $62 \%$ and $73 \%$ in the ozonated and control fruit, respectively, compared to the values at the beginning of the experiment.

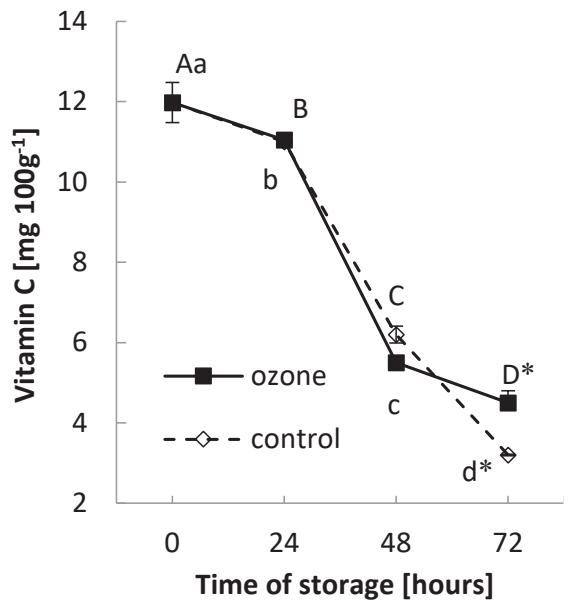

Fig. 2. Impact of ozonation on the vitamin C content in the raspberry fruit stored under ambient conditions. The mean values highlighted "*" in a given day of storage are significantly different according to the Student's t-test $(p=0.05)$. The similarity of mean values in the remaining cases is not statistically significant according to the t-Tukey test $(p=0.5)$.

The impact of ozone has been shown to be dependent on the storage procedure and the fruit type. For instance, Yeoh et al. (2014) reported that ozonation with the ozone dose of $9.2 \pm 0.2 \mathrm{ppm}$ for 10, 20 and 30 minutes resulted in various impact on the vitamin C content in papaya fruit. During 10 and 20 minutes of exposure to ozone gas the content of the vitamin $\mathrm{C}$ in papaya increased, but after 30 minutes of ozonation the vitamin C content dropped rapidly. Zhang et al. (2011) reported that presence of the ozone gas in the cooling chambers at the concentration of 2,4 or 8 ppm resulted in reduction of vitamin C losses in the strawberry fruit. The reduction of the vitamin C content in fruit is caused by high activity of ascorbic acid oxidase and ascorbic peroxidase. It is suggested that a properly chosen ozone dose has impact on the pace of vitamin C reduction, due to inactivation of oxidative enzymes. Moreover, Ali et al. (2014) suggested that higher content of ascorbic acid in ozonated fruit could be attributed to stimulation of biochemical mechanisms of vitamin C generation which is called "ozone stress" (Ali et al. 2014).

\section{Changes in the total content of phenolic compounds and anthocyanins}

The phenolic compounds are the main group of antioxidants which include flavonoids and anthocyanins. Aside of high biological value they are responsible for sensory properties of raspberry fruit. Total phenolic compounds content in raspberry fruit measured with Folin-Ciocalteu method before the storage experiment was $712.40 \pm$ $36.50 \mathrm{mg}$ in $100 \mathrm{~g}$ of fruit, calculated as a gallic acid equivalent. During the experiment it was observed that ozonation process had a positive impact on the total phenolic content in raspberry fruit (Fig. 3). Based on statistical analysis, a statistically significantly higher level of phenolics was observed in ozonated fruit than in the control fruit $(p<0.05)$. 
The loss of phenolic compounds content in the ozonated fruit was observed only after 72 hours of storage, while the phenolic content in control fruit dropped significantly already after 24 hours of storage $(p<0.05)$. Finally, at the end of the experiment, the phenolic compounds level in ozonated raspberries was $42 \%$ higher than in control fruit (Fig. 3).

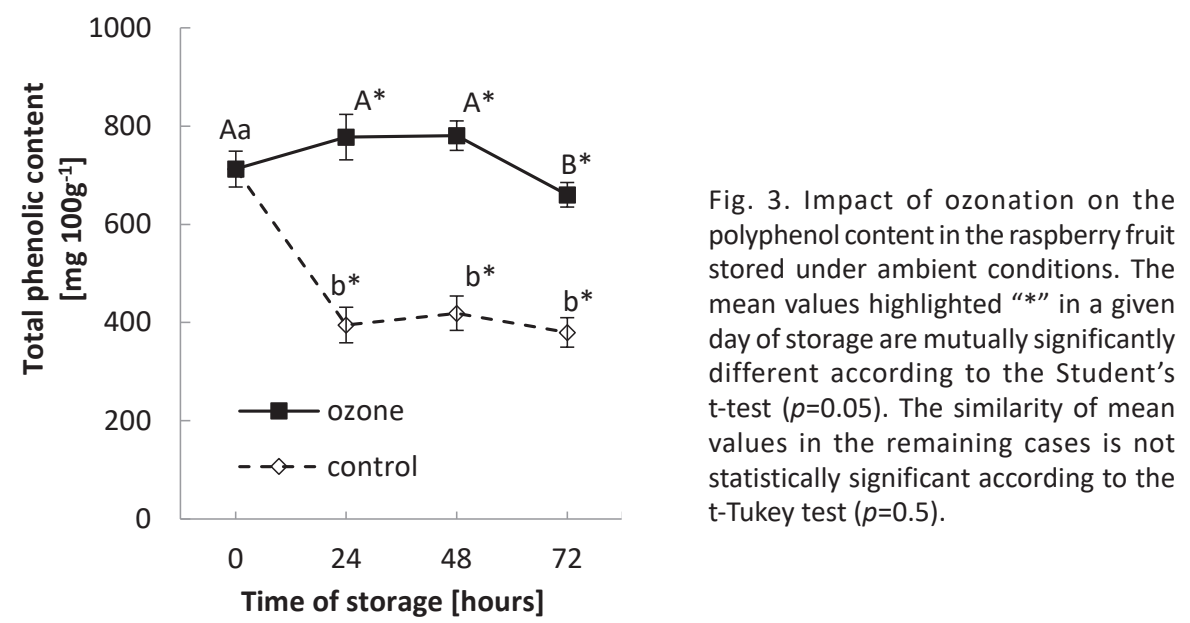

The preservation of the high level of the anthocyanin content within fruit is important mainly due to their sensory attractiveness but also pro-health properties and high antioxidant activity. It is estimated that anthocyanins accounts for $20 \%$ of the antioxidant activity of raspberry fruit (Kalisz and Wolniak 2006). The changes in the anthocyanins content within the raspberry fruit during the storage experiment for the ozonated and the control fruit are summarized in Figure 4. The initial anthocyanin content calculated as cyanidin-3-glucoside amounted $165.33 \pm 13.11 \mathrm{mg}$ per $100 \mathrm{~g}$ of raspberry fruit. Krupa and Tomala (2006) indicated steady drop of the anthocyanin content in fruit during storage. In our research, we observed a statistically significant reduction of the anthocyanins in non-ozonated sample. The utilized ozone dose and the exposition time have both contributed to inhibition of the anthocyanin degradation until 48 hours of storage. An evidence for this statement is a higher level of anthocyanin content in the ozonated fruit in comparison to the control fruit $(p<0.05)$. After 72 hours of the storage no differences in the anthocyanin content in both groups could be observed (Fig. 4).

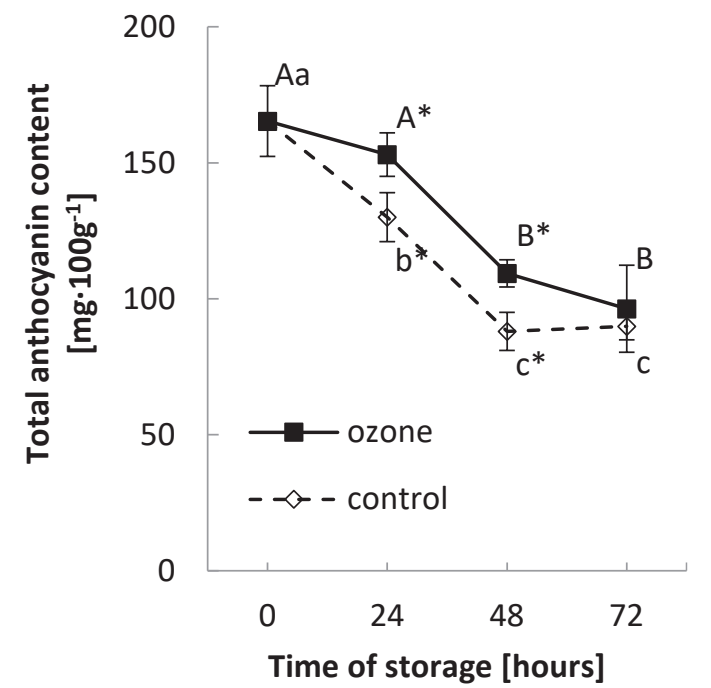

Fig. 4. Impact of ozonation on the anthocyanin content in the raspberry fruit stored under non cold storage conditions. Mean values with the same lower (changes over time for control fruit) or upper (changes over time for ozonated fruit) case are not statistically significant according to the $t$-Tukey test $(p=0.05)$. The mean values highlighted "*" in a given day of storage are mutually significantly different according to Student's t-test $(p=0.05)$.

A beneficial impact of the ozonation process on the anthocyanin content was also reported by Barth et al. (2006). They showed that ozone enriched atmosphere at the ozone concentration of $0.1 \mathrm{ppm}$ and $0.3 \mathrm{ppm}$ within the storage chamber inhibited the color loss in the marionberry fruit. Analogously, Botondi et al. (2015) observed a higher color level in the grapes ozonated once with the ozone dose $1.5 \mathrm{~g} \mathrm{~h}^{-1}$ for 18 hours and daily ozonation with the ozone dose $0.5 \mathrm{~g} \cdot \mathrm{h}^{-1}$ for 4 hours during the whole storage period. 
According to the state-of-the-art, phenolic compounds degradation during fruit storage is a result of enzymatic reactions resulting from the action of oxidoreductase enzymes mainly the polyphenol oxidase. Probably ozone inactivates oxidizing enzymes, therefore slows down or totally inhibits decomposition of phenolic compounds. Wahangchai et al. (2006) and Barth et al. (2006) observed that regardless of the time of exposition to ozone, the polyphenol oxidase activity in stored fruit was inhibited. The enzymatic process of fruit browning was not observed and the biological value resulting from the high content of polyphenols was preserved. In turn, Ali et al. (2014) suggested that a preventive effect of ozone treatment on the phenolic content is a result of the activation of enzymes responsible for polyphenols generation in fruit, e.g. phenylalanine ammonia-lyase. Therefore, it can be assumed that the effect observed in our research is dependent on the mentioned processes.

\section{Total antioxidant capacity}

In this study total antioxidant capacity was measured using three methods differing in composition of the reaction mixture and the detection conditions. Therefore, it was possible to depict the processes occurring during the storage of fruit samples. Total antioxidant capacity was determined using methods based on its ability to neutralize the synthetic radicals $\mathrm{ABTS}^{\circ+}$ and $\mathrm{DPPH}^{\circ}$, and its potential for $\mathrm{Cu}^{2+}$ reduction (CUPRAC method) (Fig. 5).

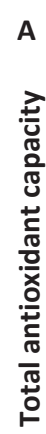

15

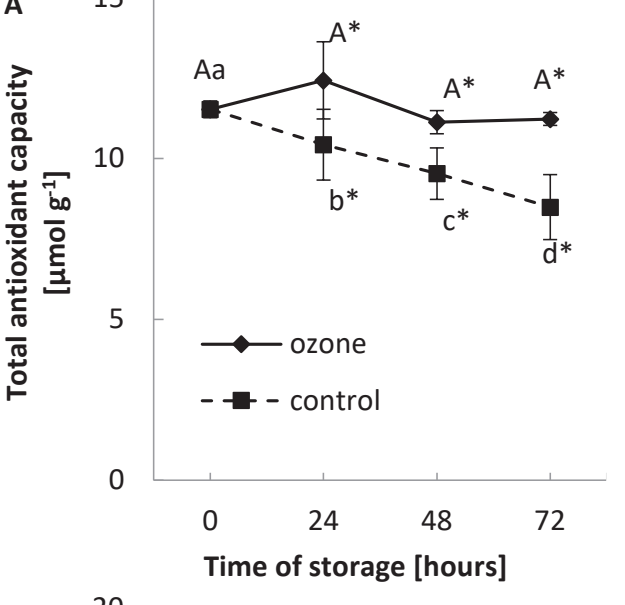

C

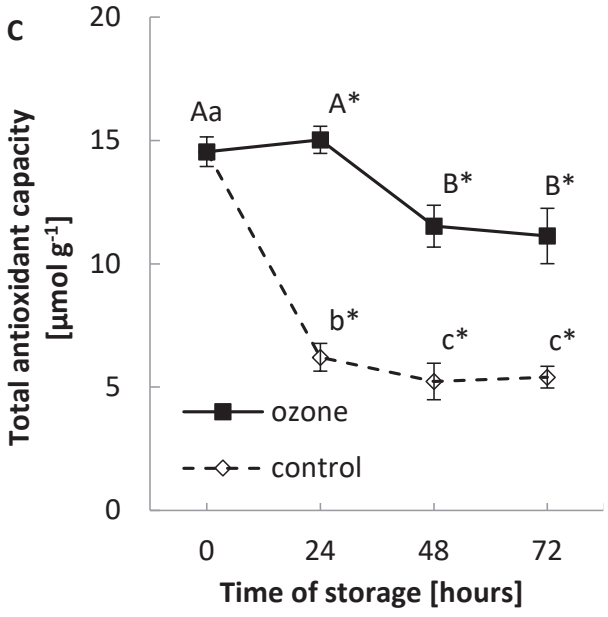

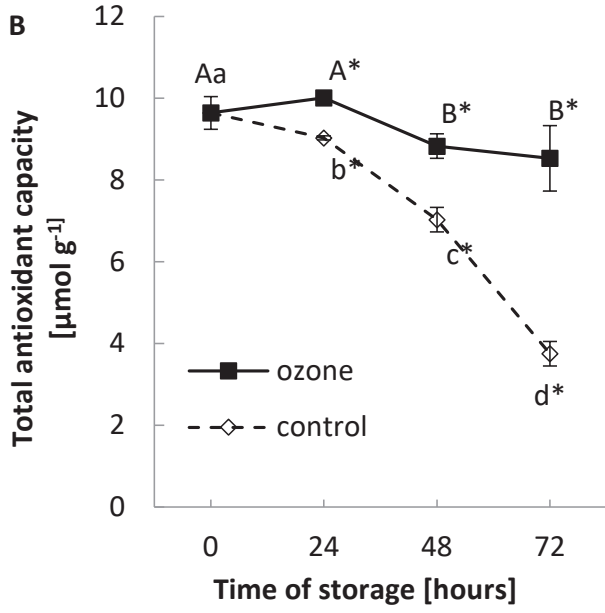

Fig. 5. Impact of ozonation on the total antioxidant capacity in the raspberry fruit stored under non cold storage conditions. The mean values highlighted "*" in a given day of storage are mutually significantly different according to the Student's t-test $(p=0.05)$. The similarity of mean values in the remaining cases is not statistically significant according to the t-Tukey test $(p=0.5)$. (A=method with $A B T S \bullet+$ radical, $B=$ method with $D P P H \cdot$ radical, $C=C U P R A C$ method).

The utilized ozonation procedure, where the raspberry fruit were ozonated with the ozone dose of 8-10 ppm for 30 min once every 12 hours during the storage period, had a statistically significant preventive impact on their antioxidant activity. Regardless of the measurement method used, the ozonated fruit were characterized by a statistically significant higher antioxidant activity in comparison to control fruit $(p<0.05)$. Prior to the storage experiments, the antioxidant capacity of investigated fruit was equal to 9.64-14.54 $\mu \mathrm{mol}$ of trolox per $1 \mathrm{~g}$ of fresh fruit mass, respectively to the chosen method of analysis (Fig. 5). During the fruit storage, a statistically significant reduction of antioxidant activity of the control fruit was observed. The ozonation process caused that the antioxidant activity measured in relation to DPPH ${ }^{\bullet}$ radical and CUPRAC test was reduced only after 24 hours of the storage and did not change statistically significantly during next hours. In addition, it was observed that the antioxidant capacity of the ozonated fruit for the $\mathrm{ABTS}^{\bullet+}$ radicals did not change significantly during the whole storage experiment $(p>0.05)$. 
Ali et al. (2014) observed that the antioxidant activity was higher in ozonated fruit in comparison to control fruit. They investigated the impact of ozone on the stability of the antioxidant compounds in papaya fruit. They observed that the fruit ozonation with the ozone dose of 1.5, 2.5 or $3.5 \mathrm{ppm}$ for 95 hours before the 10 day long storage resulted in an increase of antioxidant activity of the fruit by $0.03 \%, 30.9 \%, 21.9 \%$, respectively, in comparison to the control fruit. In turn, in the research by Giuggioli et al. (2015) no statistically significant impact of ozone treatment of raspberry fruit on the antioxidant activity was observed. The authors suggested that the ozone dose they had used was too low (500 ppb).

In our research a statistically significant correlation between the total phenolic compounds content, anthocyanins or vitamin C, and the total antioxidant capacity of investigated fruit samples was observed (Table 1). The total antioxidant capacity of the investigated raspberry fruit was determined mainly by the anthocyanin and vitamin $\mathrm{C}$ content. In turn, the remaining substances belonging to the phenolic compounds had a much smaller impact on the total antioxidant capacity. An additional cause of the differences in the values of the total antioxidant capacity is the reaction environment differing in the analytical methods mentioned. In the light of strong correlations between the qualitative properties, it is possible to suppose that changes in the total antioxidant capacity of the ozonated and control fruit depend on changes in polyphenols and vitamin C content due to the ozone impact and the interactions of individual components occurring during storage.

Table 1. Values of Pearson's linear correlation between the total antioxidant activity (CUPRAC, DPPH ${ }^{*}$, ABTS $^{\bullet+}$ ) and the total polyphenol content, anthocyanin and vitamin $\mathrm{C}$ in ozonated $\left(r_{\text {ozone }}\right)$ and non-ozonated $\left(r_{\text {cont }}\right.$ ) fruit sample $(p<0.05)$

\begin{tabular}{|c|c|c|c|c|c|c|}
\hline \multirow{2}{*}{$\begin{array}{l}\text { Pearson correlation } \\
\text { coefficients } \\
(p<0.05)\end{array}$} & \multicolumn{2}{|c|}{ Total polyphenol content } & \multicolumn{2}{|c|}{ Total anthocyanin content } & \multicolumn{2}{|c|}{$\begin{array}{c}\text { Vitamin C } \\
\text { content }\end{array}$} \\
\hline & $r_{\text {ozone }}$ & $r_{\text {control }}$ & $r_{\text {ozone }}$ & $r_{\text {control }}$ & $r_{\text {ozone }}$ & $r_{\text {control }}$ \\
\hline CUPRAC & 0.68 & 0.71 & 0.95 & 0.89 & 0.98 & 0.82 \\
\hline DPPH• & 0.61 & 0.69 & 0.91 & 0.82 & 0.94 & 0.97 \\
\hline ABTS •+ & 0.82 & 0.72 & 0.72 & 0.71 & 0.70 & 0.89 \\
\hline
\end{tabular}

\section{Conclusions}

Ozonation of the raspberry fruit with the ozone dose of 8-10 ppm for 30 min once every 12 hours during the fruit storage had a positive impact in terms of protection the fruit from development of storage diseases and inhibition of the loss of antioxidants. There were less colony forming units of mesophilic bacteria and gray mold present during the storage of raspberry fruit. The procedure used preserved the antioxidant capacity of the fruit and limited the phenolic compounds loss including anthocyanins. The utilized method had no impact on the vitamin $\mathrm{C}$ content in the fruit. The presented method was proven to be successful and its simplicity accompanied with low economic costs has a potential for utilization of ozone as a substitution for other methods used for the preservation of fruit quality during storage.

\section{References}

Ali, A., Ong, M. \& Forney, C. 2014. Effect of ozone pre-conditioning on quality and antioxidant capacity of papaya fruit during ambient storage. Food Chemistry 142: 19-26. https://doi.org/10.1016/j.foodchem.2013.07.039

Aguayo, E., Escalona, V.H. \& Ertes, F. 2006. Effect of cyclic exposure to ozone gas on physicochemical, sensorial and microbial quality of whole and sliced tomatoes. Postharvest Biology and Technology 39: 169-177. https://doi.org/10.1016/j.postharvbio.2005.11.005

Balawejder, M., Chwaszcz, B., Antos, P. \& Józefczyk, R. 2014a. Patent, PL 407854.

Balawejder, M., Józefczyk, R., Antos, P., Bilek, M., Chwaszcz, B. \& Kosowski P. 2015. Patent application, PL 412187.

Balawejder, M., Szpyrka, E., Antos, P., Józefczyk, R., Piechowicz, B. \& Sadło S. 2014b. Method of Reduction of Pesticide Residue Levels in Raspberry and Blackurrant Based on Utilization of Ozone. Ochrona Środowiska i Zasobów Naturalnych 15: 1-4.

Barth, M., Zhou, C., Mercier, J. \& Payne, F. 2006. Ozone storage effects on anthocyanin content and fungal growth in blackberries. Journal of Food Science 60: 1286-1288. https://doi.org/10.1111/j.1365-2621.1995.tb04575.x

Botondi, R., Sanctis, F., Moscatelli, N., Vettraino, A., Catelli, C. \& Mencarelli F. 2015. Ozone fumigation for safety and quality of wine grapes in postharvest dehydration. Food Chemistry 188: 641-647. https://doi.org/10.1016/j.foodchem.2015.05.029

Carletti, L., Botondi, R., Moscetti, R., Stella, E., Monacra, D., Cecchini, M. \& Massantini, R. 2013. Use of ozone in sanitation and storage of fresh fruit and vegetables. Journal of Food, Agriculture and Environment 11: 585-589. 
Chwaszcz, B., Józefczyk, R., Bilek, M. \& Balawejder, M. 2015. Ozonowanie jako metoda przedłużania trwałości przechowalniczej owoców maliny w warunkach niechłodniczych. Technologiczne kształtowanie jakości żywności. Wydawnictwo Naukowe Polskiego Towarzystwa Technologów Żywności 15-26. (in Polish).

Concha-Meyer, A., Eifert, J., Williams, R., Marcy, J. \& Welbaum, G. 2015. Shelf life determination of fresh blueberries (Vaccinium corymbosum L.) stored under controlled atmosphere and ozone. International Journal of Food Science 9: 1-9.

Giuggoli, N., Briano, R., Girgenti, V. \& Peano, C. 2015. Quality Effect of Ozone Treatment for the Red Raspberries Storage. Chemical Engineering Transaction 44: 25-30.

Giusti, M. \& Wrolstad, R. 2001. Characterization and Measurement of Anthocyanins by UV-Visible Spectroscopy. Current Protocols in Food Analytical Chemistry 1: 1-12. https://doi.org/10.1002/0471142913.faf0102s00

ISO 2009. ISO/TS 11133-1:2009. Microbiology of food and animal feeding stuffs. Guidelines on preparation and production of culture media. Part 1: General guidelines on quality assurance for the preparation of culture media in the laboratory. https:// www.iso.org/standard/46118.html

Kalisz, S. \& Wolniak, M. 2006. Zmiany związków fenolowych podczas przechowywania soków malinowych. Żywność. Nauka. Technolgia. Jakość 47: 93-100. (in Polish).

Kangasjärvi, J., Jaspers, P. \& Kollist, H. 2005. Signalling and cell death in ozone-exposed plants. Plant, Cell \& Environment 28 : 1021-1036. https://doi.org/10.1111/j.1365-3040.2005.01325.x

Khadre, M., Yousef, A. \& Kim, J. 2001. Microbiological aspects of ozone application in food. A Review. Journal of Food Science 66: 1242-1252. https://doi.org/10.1111/j.1365-2621.2001.tb15196.x

Krupa, T. \& Tomala, K. 2006. Wpływ warunków przechowywania na zawartość antocyjanów i aktywność przeciwutleniającą jagód borówki wysokiej. Żywność. Nauka. Technologia. Jakość 47: 171-181. (in Polish).

Matiacevich, S., Silva, P., Enrione, J. \& Osorio, F. 2013. Quality parameters of six cultivars of blueberry using computer vision. International Journal of Food Science 8: 1-8. https://doi.org/10.1155/2013/419535

Norberto, S., Silva, S., Meireles, M., Faria, A., Pintado, M. \& Calhau C. 2013. Blueberry anthocyanins in health promotion. A metabolic overview. Journal of Functional Foods 5: 1518-1528. https://doi.org/10.1016/j.jff.2013.08.015

Ozyurt, D., Demirata, B. \& Apak, R. 2011. Determination of total antioxidant capacity by a New Spectrofluorometric Method Based on Ce(IV) Reduction: Ce(III) Fluorescence Probe for CERAC Assay. Journal of Fluorescence 21: 2069-2076. https://doi. org/10.1007/s10895-011-0905-4

Sadło, S., Szpyrka, E., Piechowicz, B., Antos, P., Józefczyk, R. \& Balawejder, M. 2017. Reduction of Captan, Boscalid and Pyraclostrobin Residues on Apples Using Water Only, Gaseous Ozone, and Ozone Aqueous Solution. Ozone: Science and Engineering 39 : 97-103. https://doi.org/10.1080/01919512.2016.1257931

Skog, L.J. \& Chu, C.L. 2001. Effect of ozone on qualities of fruit and vegetables in cold storage. Canadian Journal of Plant Science 81: 773-778. https://doi.org/10.4141/P00-110

Tiwari, B., O'Donnel., Patras, A., Burton, N. \& Cullen, P. 2009. Anthocyanins and color degradation in ozone treated blackberry juice. Innovative Food Science and Emerging Technology 10: 70-75. https://doi.org/10.1016/j.ifset.2008.08.002

Yeoh, W.K, Ali, A. \& Forney, C. 2014. Effects of ozone on major antioxidant and microbial populations of fresh-cut papaya. Postharvest Biology and Technology 89: 56-58. https://doi.org/10.1016/j.postharvbio.2013.11.006

Wahangchai, K., Saengnil, K. \& Uthaibutra, J. 2006. Effect of ozone in combination with some organic acids on the control of postharvest decay and pericarp browning of longan fruit. Crop Protection 25: 821-825. https://doi.org/10.1016/j.cropro.2005.11.003

Zavala, J., Wang, S., Wang, C. \& Aguliar, G. 2004. Effect of storage temperatures on antioxidant capacity and aroma compounds in strawberry fruit. Food Science and Technology 37: 687-695.

Zhang, X., Zhang, Z., Wang, L., Zhang, Z., Jing, L. \& Zhang, C. 2011. Impact of ozone on quality of strawberry during cold storage. Frontiers of Agriculture in China 5: 356-360. https://doi.org/10.1007/s11703-011-1053-y 